\title{
ENTOMOLOGY
}

\section{Contribution to the knowledge of Lepidoptera fauna of Lampedusa: Bifascioides leucomelanella (Rebel, 1917) and Ceutholopha isidis (Zeller, 1867) (Lepidoptera) new to Italy}

\author{
M. Pinzari, ${ }^{1}$ M. Pinzari ${ }^{2}$ \\ ${ }^{1}$ Department of Biology, University of Roma Tor Vergata, Rome: ${ }^{2}$ Amateur entomologist, Rome, Italy
}

\begin{abstract}
For the first time, 13 species are reported for the Lepidoptera fauna of Lampedusa Island. Bifascioides leucomelanella and Ceutolopha isidis are new to Italy. The presence of Azanus ubaldus is confirmed.
\end{abstract}

\section{Introduction}

Research on Lepidoptera fauna in Central Italy has been carried out for many years and showed how much the fauna

\footnotetext{
Correspondence: Manuela Pinzari, Department of Biology, University Tor Vergata of Rome, via della Ricerca Scientifica 1, 00133 Rome, Italy.

Tel.: +39.06.72595950 - Fax: +39.06.72595965.

E-mail: manuela.pinzari@uniroma2.it

Key words: Lampedusa, Bifascioides leucomelanella, Ceutholopha isidis, Azanus ubaldus.

Acknowledgments: We thank to Dr. Marcello Romano for useful comments and suggestions on the manuscript.

Contributions: the authors contributed equally.

Conflict of interest: the authors declare no potential conflict of interest.

Funding: none.

Dedication: the article is dedicated to Anna Appolloni.

Received for publication: 10 January 2019.

Revision received: 7 August 2019.

Accepted for publication: 7 August 2019.

${ }^{\circ}$ Copyright: the Author(s), 2019

Licensee PAGEPress, Italy

Journal of Entomological and Acarological Research 2019; 51:8031

doi:10.4081/jear:2019.8031

This article is distributed under the terms of the Creative Commons Attribution Noncommercial License (by-nc 4.0) which permits any noncommercial use, distribution, and reproduction in any medium, provided the original author(s) and source are credited.
}

(Pinzari, 2016b; Pinzari \& Pinzari, 2019a,b; Pinzari et al., 2018b) and biology (Pinzari \& Sbordoni, 2013; Pinzari, 2016a, 2019; Pinzari et al., 2017, 2018a, 2019, 2019a) of Lepidoptera in Italy are still scarcely known. Recently, the survey has also been extended to the southern Italy and isles leading results that prompt further investigation.

During a short survey on Lepidoptera fauna in Lampedusa we collected a few species that are still unknown for the island. Although short surveys lead to the collection of few specimens and species, however they can reveal interesting species of biogeographic relevance (e.g., Acleris lorquiniana (Duponchel, 1835), rare species in Italy, Pinzari \& Pinzari, 2013; Scythris clavella (Zeller, 1855), new to Peninsular Italy, Pinzari, 2016; Clepsis peritana (Clemens, 1860), an alien species, Pinzari et al., 2018) and give an important contribution in shaping their distribution in Italy.

In this framework, we report the species newly recorded for Lampedusa and confirm the presence through time in the island also of some species already sighted in the past.

\section{Materials and Methods}

The Lepidoptera were collected from July 16th to 22nd, 2018. A variety of systems has been employed in order to survey as many Lepidoptera species as possible: netting for the dayactive species; lamp (Mixed Light $160 \mathrm{~W}$ ), which was mounted in a fixed site (terrace) with electricity available in the centre of the town of Lampedusa; and, finally pheromone baits for Sesiidae moths.

The specimens are deposited in the private collection of Mario Pinzari (Rome, Italy).

\section{Checklist of species new to Lampedusa}

\section{Plutellidae}

Plutella xylostella (Linnaeus, 1758)

ReCords. 1 §ิ, Lampedusa (city), 16.VII.2018; M. \& M. Pinzari leg. 


\section{Cosmopterigidae}

Bifascioides leucomelanella (Rebel, 1917) (Figure 1A)

ReCords. 1 ô, Lampedusa (city), 18.VII.2018; M. \& M. Pinzari leg.

LIFE HISTORY. Biology unknown. In Malta, adults have been collected in February and from May till the end of August. There is probably more than one generation (Koster \& Sammut, 2006).

\section{Gelechiidae}

Tuta absoluta (Meyrick, 1917)

ReCords. 1 q (gen. praep. GELE 933 M. Pinzari), Lampedusa (city), 16.VII.2018; M. \& M. Pinzari leg.

\section{Tortricidae}

Lobesia botrana ([Denis \& Schiffermüller], 1775)

Records. 3 $\widehat{\jmath}$, Lampedusa (city), 16.VII.2018; M. \& M. Pinzari leg.

\section{Pyralidae}

Ceutholopha isidis (Zeller, 1867) (Figure 1B)

RECORDS. 1 q (gen. praep. PIRA 432 M. Pinzari), Lampedusa (city), 16.VII.2018; M. \& M. Pinzari leg.

LIFE HISTORY. Akin (2018) mentioned as host plants Acacia tortilis (Forssk.) Hayne, A. farnesiana (L.) Willd., A. nilotica (L.) Delile (Fabaceae) and Rhus oxyacantha Aubrév. (Anacardiaceae) (Leraut, 2014; De Prins and De Prins, 2018).

Euzophera bigella (Zeller, 1848)

ReCords. 1 q (gen. praep. PIRA 431 M. Pinzari), Lampedusa (city), 18.VII.2018, M. \& M. Pinzari leg.

Ephestia welseriella (Zeller, 1848)

Records. 1 ô (gen. praep. PIRA 435 M. Pinzari), Sciatu Persu, 18.VII.2018; M. Pinzari leg.

Cadra calidella (Guenée, 1845)

ReCORds. 1 q (gen. praep. PIRA 433 M. Pinzari), Lampedusa (city), 16.VII.2018, 1 + (gen. praep. PIRA 434 M. Pinzari), idem, 21.VII.2018; M. \& M. Pinzari leg.

\section{Erebidae}

Pandesma robusta (Walker, 1858) (Figure 1C)

ReCords. 1 ô, Lampedusa (city), 16.VII.2018; M. \& M. Pinzari leg.

Hypena lividalis (Hübner, 1796)

RECORDS. 1 ô, Lampedusa (city), 16.VII.2018; M. \& M. Pinzari leg.

Eublemma parva (Hübner, 1808)

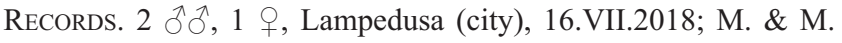
Pinzari leg.

\section{Noctuidae}

Helicoverpa armigera (Hübner, 1808)

ReCORDS. 1 ơ, Lampedusa (city), 21.VII.2018; M. \& M. Pinzari leg.

Spodoptera cilium Guenée, 1852

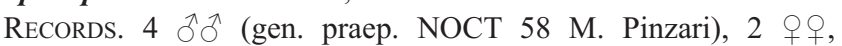
Lampedusa (city), 16.VII.2018; M. \& M. Pinzari leg.

\section{Other species}

Bembecia hymenopteriformis (Bellier, 1860) (Aistleitner \& Aistleitner, 2001)

RECORDS. $3 \hat{\jmath} \hat{\partial}$, Cala Francese, 17.VII.2018, $14 \hat{\jmath} \hat{\jmath}$, idem, 20.VII.2018; $2 \hat{\partial} \hat{\partial}$, Sciatu Persu, 18.VII.2018, $3 \hat{\jmath} \hat{\partial}$, idem, 21.VII.2018, $2 \delta^{\lambda} \hat{\jmath}$, idem, 22.VII.2018; $1 \hat{\delta}, 35^{\text {th }}$ parallel north, 50 m, 19.VII.2018; 1 §, Cala Pulcino, 19.VII.2018; 1 त, Cala Croce, 20.VII.2018; $3 \hat{\jmath} \hat{\jmath}$, Cala Pisana, 21.VII.2018. M. \& M. Pinzari leg.

Aporodes floralis (Hübner, 1809) (Ragusa, 1892)

Records. 1 ô, Lampedusa (city), 20.VII.2018; M. \& M. Pinzari leg. Hellula undalis (Fabricius, 1781) (Prola. In Zavattari, 1960): RECORDS. 1 ô, Lampedusa (city), 18.VII.2018; M. \& M. Pinzari leg.

Hydriris ornatalis (Duponchel, 1832) (Prola. In: Zavattari, 1960) Records. 1 §ै, Lampedusa (city), 18.VII.2018; M. \& M. Pinzari leg. Herpetogramma licarsisalis (Walker, 1859) (Fiumi \& Guidi, 2011): ReCords. 1 ๙ (gen. praep. PIRA 435 M. Pinzari), Cala Francese, 17.VII.2018; M. Pinzari leg.

Pieris brassicae (Linnaeus, 1758) (Calcara, 1847)

RECORDS. 4 pupae, Lampedusa (city), 18.VII.2018; M. \& M. Pinzari leg.

Leptotes pirithous (Linnaeus, 1767) (Vodă et al., 2016)

RECORDS. $1 \hat{\jmath}, 1$ †, Sciatu Persu, 18.VII.2018; $2 \hat{\jmath} \hat{\jmath}, 1$ ㅇ, Lampedusa (city), 16.VII.2018; M. Pinzari leg.

Azanus ubaldus (Stoll, [1782]) (Figure 1D) (Caporale \& Guidi, 2013)

ReCords. 13 ổ, 1 o, Sciatu Persu, 22.VII.2018, M. Pinzari leg.

Polyommatus celina (Austaut, 1879) (Prola. In Zavattari, 1960, sub P. icarus; Vodă et al., 2015)

RECORDS. 1 ô, 1 \&, Cala Francese, 17.VII.2018; M. Pinzari leg.

Rhodometra sacraria (Linnaeus, 1767) (Prola. In: Zavattari, 1960; Fiumi et al., 2007)

RECORDS. 1 q, Lampedusa (city), 16.VII.2018, 1 ô, idem, 18.VII.2018; M. \& M. Pinzari leg.

Gymnoscelis rufifasciata (Haworth, [1809]) (Romano \& Romano, 1995)

ReCords. 1 , Lampedusa (city), 16.VII.2018; M. \& M. Pinzari leg.

Heliothis peltigera (Denis \& Schiffermüller, 1775) (Prola. In: Zavattari, 1960)

RECORDS. $1 \hat{\jmath}$, Lampedusa (city), 16.VII.2018, 1 †, idem, 17.VII.2018; M. \& M. Pinzari leg.

\section{Conclusions}

The sample of species collected in the study area, although quantitatively small, confirms the importance but also the fragility of the fauna of Lampedusa as a bridge between Europe and Africa.

In fact, biogeographically interesting species coexist in Lampedusa with alien species and pests from the rest of the world.

Bifascioides leucomelanella (Figure 1A), and Ceutholopha isidis (Figure 1B) and Pandesma robusta (Figure 1C) represent 

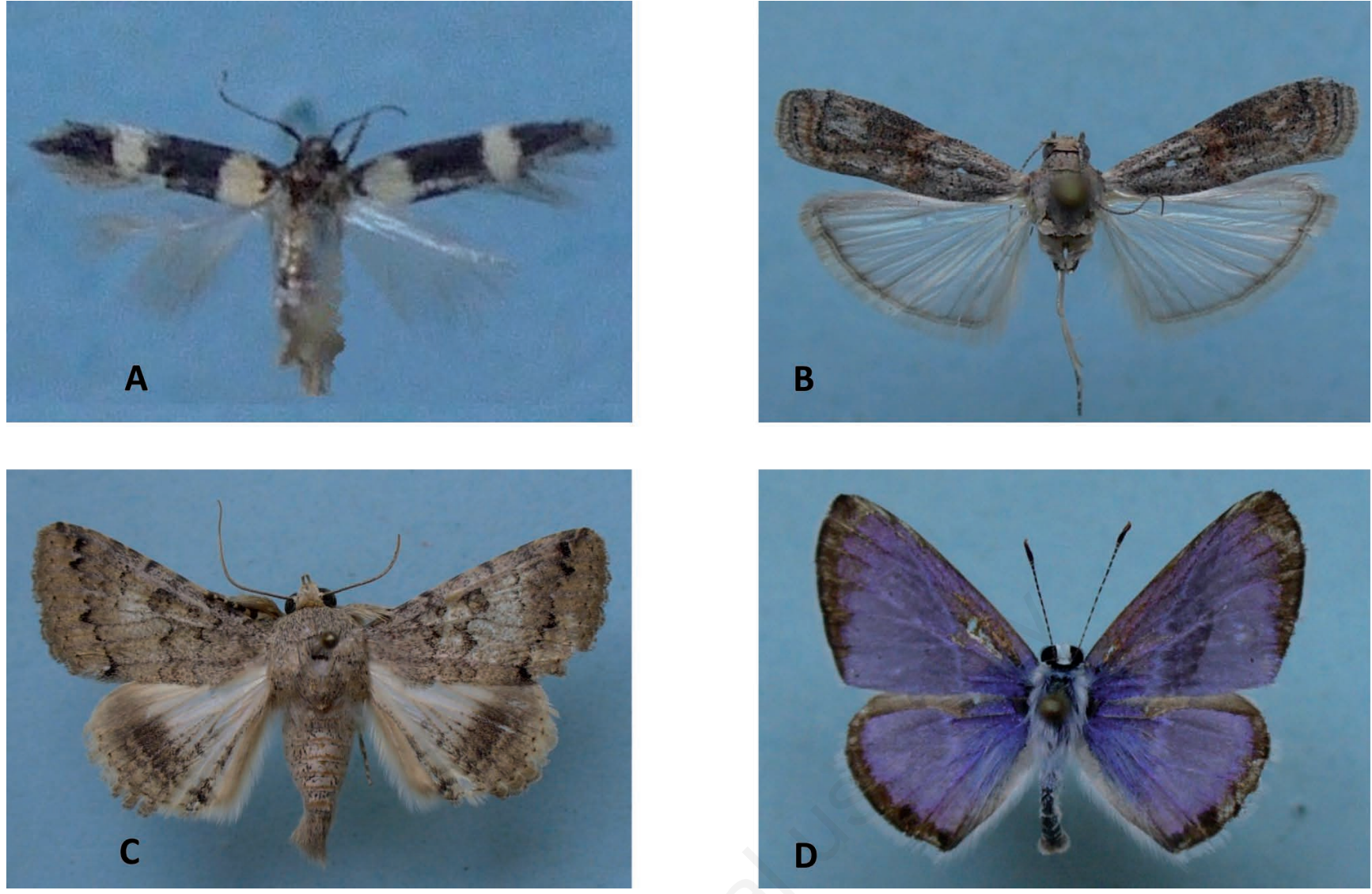

Figure 1. A) Bifascioides leucomelanella (Rebel, 1917) $\hat{\jmath}$, wingspan 7 mm; B) Ceutholopha isidis (Zeller, 1867) $\circ$, wingspan 16 mm; C) Pandesma robusta (Walker, 1858) $\gamma^{2}$, wingspan $41 \mathrm{~mm}$; D) Azanus ubaldus (Stoll, [1782]) $\hat{\gamma}$, wingspan $20 \mathrm{~mm}$.

some examples. As concerns the first two species, we record them for the first time in Lampedusa. Bifascioides leucomelanella was sighted in Europe only for Malta (Koster \& Sammut, 2006) while C. isidis, which is widely spread up to Africa South and India, was recorded in Portugal (Corley et al., 2014), in Spain, Malta and England (Revilla \& Gaston, 2014). Pandesma robusta (Figure 1C) is a rare African migrant that has never been reported before for Lampedusa but is known for Pantelleria (Aistleitner \& Aistleitner, 2001), Sicily (Bella \& Russo,1999; Zafarana et al., 2017), Calabria (Scalercio \& Parenzan, 2000) and Latium (Zilli et al., 2001).

We can confirm therefore the presence of Azanus ubaldus (Figure 1D) which was observed for the first time on Lampedusa in 2010 at Albero Sole by Caporale and Guidi (2013). It is a Paleotropical species, common from the dry areas in Southern Africa to Somalia in Eastern Africa (D'Abrera, 2009). It has presumably spread from N. Africa where the species is present in Algeria, Tunisia and Egypt (Tolman \& Lewington, 1997). The presence of the taxon on the island can be considered to be stable not to derive from random migrations from Mediterranean coasts of the North-African countries. In fact, we observed several males of $A$. ubaldus that were resting on the tips of the dry branches of bushes surrounding flowers of Acacia karoo Hayne. They presumably waited for intercepting quickly flying females around the acacias. In Lampedusa, Acacia karoo may be the main food source in summer for this taxon (Caporale \& Guidi, 2013) and other species recorded (e.g. Leptotes pirithous adults fed on flowers).

Unexpectedly, we did not find either adults and caterpillars of
Danaus chrysippus (Linnaeus 1758) as reported by Arnone and Romano (1991) on Caralluma europaea (Guss.) N.E.Br. (Pisciotta et al., 2008), or individuals of Zizeeria karsandra (Moore, 1865) (sub. knysna)(Romano \& Romano, 1995).

All other species listed in this paper and recorded for the first time in Lampedusa are widely spread in Europe and in particular in Italy (including Sicily) and Malta (Karsholt \& Razowski, 1996; Karsholt \& Nieukerken van, 2013).

Finally, it is important to mention also the presence in Lampedusa of ubiquitous and widespread species throughout Europe and in most of the world: Plutella xylostella (Linnaeus, 1758), Helicoverpa armigera (Hübner, 1808), Tuta absoluta (Meyrick, 1917), Euzophera bigella (Zeller, 1848) and Lobesia botrana ([Denis \& Schiffermüller], 1775). The last three species are pests of tomato (T. absoluta, Desneux et al., 2011), fruits and olive (E. bigella, Simoglou et al., 2012), and grape (L. botrana, Duso et al., 1992). They are already known for Malta (Andria \& Catenia, 2009). Tuta absoluta is a very challenging pest to control because of its parthenogenetic reproduction and polygynic nature of males (Megido et al., 2013).

\section{References}

AISTLEITNER E., AISTLEITNER U., 2001 - Weitere Notizen zur Lepidopterenfauna von Pantelleria, den Pelagischen und 
Agadischen Inseln (Italian, Sizilien). - Z. Arbeitsgemeinschaft Österreichischer Entomol. 53: 93-100.

AKIN K., 2018 - Ceutholopha isidis (Zeller, 1867), a New Phycitinae Record from Turkey (Lepidoptera: Pyraloidea). - J. Entomol. Res. Soc. 20: 119-122.

ANDRIA D., CATENIA A., 2009 - Tuta absoluta (Povolny, 1994), an important agricultural pest in Malta (Lepidoptera: Gelechiidae). - Bull. Entomol. Soc. Malta 2: 57-60.

ARNONE M., ROMANO M., 1991 - Nuovi reperti di Danaus chrysippus (Linnaeus, 1758) in Sicilia (Lepidoptera, Danaidae). - Naturalista Sicil. S. IV, XV: 161-166.

BELLA S., RUSSO P., 1999 - Pandesma robusta new to the Italian fauna (Lepidoptera, Noctuidae). - Esperiana 7: 472.

CALCARA P., 1847 - Descrizione dell'isola di Lampedusa. Stamperia di Raffaele Pagano, Palermo: 45 pp.

CAPORALE F., GUIDI M., 2013 - Azanus ubaldus (Stoll, 1782) nuovo per l'Italia (Lepidoptera Lycaenidae). - Boll. Soc. Entomol. Ital. 145: 87-89.

CORLEY M. F. V., ROSETE J., MARABUTO E., MARAVALHAS, E., PIRES P., 2014. - New and interesting Portuguese Lepidoptera records from 2013 (Insecta: Lepidoptera). - SHILAP Rev. Lepidopterol. 42: 587-613.

D'ABRERA B. (Ed), 2009 - Lycaenidae, Rhiodinidae. In: Butterflies of the Afrotropical region. Hill House Publishers: 816-817.

DE PRINS J., DE PRINS W., 2018 - Afromoths, online database of Afrotropical moth species (Lepidoptera). Available at: www.afromoths.net

DESNEUX N., LUNA M.G., GUILLEMAUD T., URBANEJAA., 2011 - The invasive South American tomato pinworm, Tuta absoluta, continues to spread in Afro-Eurasia and beyond: the new threat to tomato world production. - J. Pest Sci. 84: 403408.

DUSO C., MOLINARI F., PASQUALINI E., 1992 - Lobesia botrana (Denis \& Schiffermüller). In: ZANGHERI S., BRIOLINI G., CRAVEDI P. (Eds), Lepidotteri dei fruttiferi e della vite. Ed. L'Informatore Agrario, Milan, Italy: 85-88.

FIUMI G., GUIDI G. 2011 - Segnalazioni faunistiche. 110. Herpetogramma licarsisalis (Walker, 1859) (Lepidoptera Crambidae). - Quad. Studi Nat. Romagna 32: 203.

FIUMI G., GUIDI M., FOLIGATTI I. 2007 - Interessanti reperti della lepidotterofauna italiana raccolti nell'isola di Lampedusa (Insecta Lepidoptera). - Quad. Studi Nat. Romagna 24: 107116.

KARSHOLT O., NIEUKERKEN VAN E.J., 2013 - Lepidoptera. Fauna Europaea Web Service,. version 2.6.2. Available from: http://www.faunaeur.org

KARSHOLT O., RAZOWSKI J. 1996. The Lepidoptera of Europe, a distributional checklist. Apollo Books, Stenstrup: 380 pp.

KOSTER S.J.C., SAMMUT P., 2006 - Faunistic notes on Momphidae, Batrachedridae, Stathmopodidae and Cosmopterigidae from the Maltese Islands. Nota Lepidopterol. 29: 49-63.

LERAUT P., 2014 - Moths of Europe. Vol. 4: Pyralids 2. N.A.P. Editions: $440 \mathrm{pp}$.

MEGIDO R.C., HAUBRUGE É., VERHEGGEN F.J., 2013 Pheromone-based management strategies to control the tomato leafminer, Tuta absoluta (Lepidoptera: Gelechiidae). A review. - Biotechnol. Agron. Soc. Environ. 17: 475-482.

PINZARI M., 2016a - Deraeocoris schach, a new predator of Euphydryas aurinia and other heteropteran feeding habits on caterpillar web (Heteroptera: Miridae; Lepidoptera: Nymphalidae). - Fragm. Entomol. 48: 77-81.
PINZARI M., 2016b - Scythris clavella (Zeller, 1855) in Italy (Lepidoptera, Gelechioidea Scythrididae). - J. Entomol. Acarol. Res. 48: 301-303.

PINZARI M., 2019 - Phylloneta sisyphia (Araneae: Theridiidae), a predator of larvae of Euphydryas aurinia (Lepidoptera: Nymphalidae) and its parasitoid Erycia furibunda (Diptera: Tachinidae). - Acta Zool. Bulgar. 71: 195-200.

PINZARI M., PINZARI M., 2013 - Acleris lorquiniana (Lepidoptera: Tortricidae), in Central Italy. - J. Entomol. Acarol. Res. 45: 12-13.

PINZARI M., PINZARI M., 2019a - Genus Delplanqueia Leraut, 2001 and D. inscriptella (Duponchel, 1836) (Lepidoptera: Pyralidae) in Italy. - J. Entomol. Acarol. Res. 51: 8168.

PINZARI M., PINZARI M. 2019b - Genus Pempeliella Caradja, 1916 and $P$. bayassensis Leraut, 2001 (Lepidoptera, Pyralidae) in Italy. - ZooKeys 854: 131-144.

PINZARI M., CIANFERONI F., FABIANI A., DIOLI P., 2019a Predation by nymphs of Picromerus bidens (Heteroptera: Pentatomidae, Asopinae) on caterpillars of Euphydryas aurinia provincialis (Lepidoptera: Nymphalidae) in Italy. - Redia 102: 89-94.

PINZARI M., PINZARI M., SBORDONI V., 2017 - Notes on Life-History of Erycia furibunda (Diptera: Tachinidae), A parasitoid of Euphydryas aurinia provincialis (Lepidoptera: Nymphalidae). - Redia 100: 81-87.

PINZARI M., PINZARI M., SBORDONI V., 2019b - Make it simple: mating behaviour of Euphydryas aurinia provincialis (Lepidoptera: Nymphalidae). - Eur. Zool. J., 86: 220-232.

PINZARI M., SANTONICO M., PENNAZZA G., MARTINELLI E., CAPUANO R.M., PAOLESSE R., DI RAO M., D'AMICO A., CESARONI D., SBORDONI V., DI NATALE C., 2018a Chemically mediated species recognition in two sympatric Grayling butterflies: Hipparchia fagi and Hipparchia hermione (Lepidoptera: Nymphalidae, Satyrinae). - PLoS ONE 13: e0199997.

PINZARI M., SBORDONI V., 2013 - Species and mate recognition in two sympatric Grayling butterflies: Hipparchia fagi and H. hermione genava (Lepidoptera). - Ethol. Ecol. Evol. 25: 2851.

PINZARI M., ZERUNIAN Z., PINZARI M., 2018b - Is the alien species Clepsis peritana (Lepidoptera: Tortricidae) settling in Italy? - J. Entomol. Acarol. Res. 50: 7551.

PISCIOTTA S., ZITO P., SAJEVA M., 2008 - Danaus chrysippus (Linnaeus, 1758) (Lepidoptera Nymphalidae) larvae feeding on Caralluma europaea (Guss.) N.E.BR. (Asclepiadaceae) in Lampedusa island. - Naturalista Sicil. S. IV, XXXII: 241-51.

PROLA C., 1960 - Fauna, Lepidoptera. In: Zavattari E., Biogeografia delle Isole Pelagie. - Rendiconti Accademia Nazionale dei XL, 11: 349-358.

RAGUSA E., 1892. Breve gita entomologica all'Isola di Lampedusa. - Naturalista Sicil. 11: 234-238.

REVILLA T.X., GASTÓN J., 2014 - Ceutholopha isidis Zeller, 1867, nuevo phycitinae para la peninsula iberica (Lepidoptera: Pyralidae: Phycitinae). - Boletín de la Sociedad Entomológica Aragonesa (S.E.A.) 54: 340-341.

ROMANO F.P., ROMANO M., 1995 - Lepidoptera. In: Massa B. Arthropoda di Lampedusa, Linosa e Pantelleria (Canale di Sicilia, Mar Mediterraneo). - Naturalista Sicil. S. XIX: 693722.

SCALERCIO S., PARENZAN P., 2000 - Pandesma robusta (Walker, 1858) (Noctuidae, Catocalinae) e Calamodes subscudularia (Turati, 1919) (Geometridae, Ennominae), specie nuove per la fauna dell'Italia continentale (Lepidoptera). Entomologica 34:133-42. 
SIMOGLOU K.B., KARATARAKI A., RODITAKIS N. E., RODITAKIS E., 2012 - Euzophera bigella (Zeller) (Lepidoptera: Pyralidae) and Dasineura oleae (F. Low) (Diptera: Cecidomyiidae): Emerging olive crop pests in the Mediterranean? - J. Pest Sci. 85: 169-177.

TOLMAN T., LEWINGTON R., 1997 - Collins Field Guide Butterflies of Britain \& Europe. Harper Collins, London: 85 pp. VODĂ R., DAPPORTO L., DINCĂ V., VILA R., 2015 - Why do cryptic species tend not to co-occur? A case study on two cryptic pairs of butterflies. - PLoS One 10: e0117802.

VODĂ R., DAPPORTO L., VLAD DINCĂ V., SHREEVE T.G.,
KHALDI M., BARECH G., REBBAS K., SAMMUT P., SCALERCIO S., HEBERT P.D.N., VILA R., 2016 - Historical and contemporary factors generate unique butterfly communities on islands. - SHILAP Rev. Lepidopterol. 6: 28828.

ZAFARANA M.A., ZAFARANA S., LEOTTA R., 2017 - Nuove osservazioni di Pandesma robusta (Walker, 1858) (Lepidoptera Noctuoidea Erebidae) in Sicilia. - Naturalista Sicil. S. IV, XLI: 107-108.

ZILLI A., MALTZEFF P., PINZARI M., RAINERI V. 2001 - I Lepidotteri della Tenuta Presidenziale di Castelporziano (Lepidoptera). - Boll. Assoc. Rom. Entomol. 56: 13-48. 